\title{
Die afbreek van woorde aan reëleindes
}

Afrikaans, en spesifiek Standaardafrikaans, het tot die volwaardige kultuur- of wetenskapstaal wat ons vandag ken en gebruik, ontwikkel (a) omdat die spelling en skryfwyse daarvan doelbewus gestandaardiseer is en (b) veral omdat die Afrikaanssprekende gemeenskap aktief deelgeneem het aan die uitbouing en ontwikkeling van die taal en dit gebruik het.

In die huidige politieke en maatskaplike klimaat is dit opnuut van kardinale belang dat ons ons taal op alle vlakke gebruik, dit behoorlik gebruik en die gevestigde norme daarvan handhaaf. Wat (a) hier bo betref, het die Akademie'n deurslaggewende rol gespeel deur middel van sy Taalkommissie en die publikasie van die Afrikaanse woordelys en spelreëls (AWS). Daarom wil ek hierdie jaar in die Taalrubriek opsommenderwys en slegs in breë trekke party van die $A W S$ se reëls behandel.

As 'n mens skryf, is dit soms nodig of gerieflik om 'n woord wat nie volledig aan die einde van 'n reël inpas nie, af te breek. Dit gebeur veral as 'n mens met die hand skryf, of as teks wat op watter manier ook al geset en gedruk word, regs "geblok" of gejusteer word. Nie alle rekenaarprogramme kan egter woorde korrek volgens die Afrikaanse stelsel afbreek nie; daarom sien mens soms in die media die vreemdste afbrekings.

Van die belangrikste afbreekreëls is die volgende:

1. Afrikaans breek by voorkeur volgens betekenisvolle dele af (hier onder verteenwoordig die koppelteken 'n afbreekpunt). Daarom breek ons biochemie af as bio-chemie, en nie byvoorbeeld bi-ochemie of bioch-emie nie, en verstewig as ver-stewig en nie vers-tewig nie.

2. 'n Tweede belangrike reël is dat ons volgens lettergrepe afbreek. Daarom kan vriendin as vrien-din afgebreek word, en kluisenaar op een van twee plekke: klui-se-naar.

\section{MAAR:}

3. Afbreking volgens betekenisvolle dele geld slegs indien die betekenisvolle dele met die lettergrepe ooreenstem. Daarom breek ons vriendin nie af as vriend-in nie; laasgenoemde is wel volgens betekenisvolle dele, maar dit stem nie met die lettergrepe ooreen nie. Insgelyks word handeling nie as handel-ing afgebreek nie, maar as han-de-ling, omdat laasgenoemde met die lettergrepe ooreenstem.

4. Voorts moet 'n mens probeer om altyd herkenbaarheid te handhaaf, dit wil sê jy moet probeer om die leser nie te laat struikel nie. Daarom moet herenig liefs as her-enig afgebreek word, en nie as here-nig nie, en bedeling as be-deling en nie bede-ling nie.

Bostaande is waarskynlik die afbreekreëls wat die meeste gebruik word, maar ek noem baie kortliks drie ander:

5. Indien 'n vokaalletter $(a, e, i, o, u)$ wat nie deel van'n diftong ofte wel'n tweeklank uitmaak nie, direk voor of ná 'n diftong staan, word tussen die twee afgebreek, byvoorbeeld geys word ge-ys en skouer word skou-er. (Ek het al teëgekom dat skooljuffrouens die kinders leer dat iets soos $-a a$ - of -oo-'n tweeklank is, wat natuurlik nie korrek is nie.) 
6. Ongeag die uitspraak word altyd tussen'n - $n$ - en 'n - $g$-afgebreek, byvoorbeeld angel $\rightarrow$ angel; angora $\rightarrow$ an-gora; anglisisme $\rightarrow$ an-glisisme; wangedrag $\rightarrow$ wan-gedrag. Vanselfsprekend geld hierdie reël nie as die -ng-aan die einde van die eerste lid van'n samestelling voorkom nie, byvoorbeeld slangbyt of wangspiere word slang-byt en wang-spiere, nie slan-gbyt of wan-gspiere nie!

7. Wanneer 'n - $s$ - en 'n -j- langs mekaar staan, word tussen die twee afgebreek indien hulle as twee verskillende klanke uitgespreek word, byvoorbeeld asjas $\rightarrow$ as-jas; morsjors $\rightarrow$ morsjors. As die twee egter as een klank uitgespreek word, word die twee nie geskei nie, byvoorbeeld mansjet $\rightarrow$ man-sjet; bolsjewiek $\rightarrow$ bol-sjewiek; hasjisjpyp $\rightarrow$ ha-sjisj-pyp . Terloops, laasgenoemde reël verklaar waarom brosjure afgebreek word as bro-sju-re en nie bros-ju-re nie, wat die verkeerde uitspraak sou verteenwoordig.

Hierdie en die ander afbreekreëls word deeglik met duidelike voorbeelde bespreek in hoofstuk 1 van die Spelreëls in die $A W S$. Gebruikers word aangemoedig om dié Akademiepublikasie, waarvan die nuutste (11de) uitgawe ook aanlyn beskikbaar is, te gebruik.

Ek herhaal ook graag die uitnodiging dat lesers vrae oor praktiese gebruikskwessies kan instuur, wat ek dan in 'n rubriek sal probeer behandel.

JD (Tом) McLachlan

tommcl@whalemail.co.za 